A R T I G O

\title{
O RIO DA PRATA, A INDEPENDÊNCIA E A ABOLIÇÃO: PERSPECTIVAS DE LIBERDADE DOS ESCRAVOS NO ALÉM-FRONTEIRA
}

La Plata River, Independence and Abolition: Perspectives of Freedom of the Slaves Beyond the Frontier

El Río de la Plata, la independencia y la abolición: perpspectivas de libertad de los esclavos más allá de la frontera

\section{HEVELLY FERREIRA ACRUCHE ${ }^{I^{*}}$}

\footnotetext{
'Universidade Federal do Rio de Janeiro (UFRJ), Rio de Janeiro - RJ, Brasil.

*Formada em História pela Universidade Federal do Estado do Rio de Janeiro (UNIRIO), com Mestrado e Doutorado em História pela Universidade Federal Fluminense (UFF). Atualmente, é professora de História na Secretaria de Estado e Educação do Rio de Janeiro (SEEDUC), Professora Substituta de História da América na UFRJ e Professora Adjunta no curso de História e Pedagogia das Faculdades Unyleya. (hfacruche@gmail.com),

ORCID iD: https://orcid.org/0000-0003-4895-6629
}

Artigo recebido em 15 de Novembro de 2018 e aceito para publicação em 12 de fevereiro de 2019. 


\section{RESUMO}

o presente artigo tem por objetivo analisar as possibilidades de liberdade de escravos oriundos de terras do Brasil para as colônias espanholas no contexto das lutas pela independência política ocorridas a partir de 1810. Procuramos dar um panorama da política nesse período e apresentar algumas trajetórias negras no decorrer destas lutas, sobretudo após a publicação da lei de 1813 e do decreto que permitia aos escravos vindos de terras estrangeiras a aquisição da liberdade.

PALAVRAS-CHAVE: Liberdade; Escravidão; Guerras de independência.

\section{ABSTRACT}

Abstract: The present article aims to analyze the possibilities of freedom of slaves from Brazil to Spanish colonies in the context of the political independence struggles that took place ever since 1810 . We sought to give an overview of the strategy in this period and to present some life stories of black people in the course of these struggles, mainly after the publication of the law of 1813 and the decree that allowed slaves coming from foreign lands to acquire freedom.

KEYWORDS: Freedom; Slavery; independence wars.

\section{RESUMEN}

El presente artículo tiene por objetivo analizar las posibilidades de libertad de esclavos oriundos de tierras de Brasil hacia las colonias españolas en el contexto de las luchas por la independencia política ocurridas a partir de 1810 . Buscamos dar un panorama de la política en ese período y presentar algunas trayectorias negras en el transcurso de estas luchas, sobre todo después de la publicación de la ley de 1813 y del decreto que permitía a los esclavos provenientes de tierras extranjeras la adquisición de la libertad.

PALABRAS CLAVE: Libertad; Esclavitud; Guerras de independencia. 


\section{INTRODUÇÃO}

$\mathrm{O}$ ano de 1808 foi fundamental para os processos separatistas envolvendo a América hispânica e a Europa. Apesar de França e Espanha serem aliadas políticas e terem um relacionamento cordial desde o Tratado de Basileia (1795), a saída de Fernando VII do poder e a ascensão do francês José Bonaparte em seu lugar era inaceitável. Para François-Xavier Guerra, a crise inaugurada em 1807 era inesperada, e sua dinâmica contribuiu para uma mudança ideológica na América. Tanto para espanhóis quanto para os colonos, os eventos que culminaram na abdicação de Bayona foram uma traição de um país que era aliado da Espanha, um "ato de força pura" (Guerra, 1994: 198-200).

Uma fração da elite espanhola cogitava uma reforma da monarquia inspirada em valores franceses, porém, sem a eclosão de uma revolução. A resistência contra Napoleão, iniciada sob termos tradicionais, mesclava atitudes e princípios de ideias revolucionárias e liberais (Neves, 2010). Entretanto, o universo colonial experimentava problemas envolvendo a aplicação das chamadas Reformas Bourbônicas, cujo impacto contribuiu para o descontentamento das elites criollas com a maior centralização importa pela Coroa, ameaçando sentimentos de autonomia e identidade em fins do século XVIII. Assim, podemos pensar no impacto destas reformas no conjunto colonial hispânico; os quais com os acontecimentos de 1807 ficaram mais aflorados (Mäder; Pamplona, 2007: 226).

Diante do vazio de poder e da não aceitação de um governante estrangeiro tanto na Espanha quanto em suas colônias americanas, a criação de Juntas de governo foi uma primeira iniciativa, a qual também pode ser vista como uma instância revolucionária. Na falta do rei, a soberania era do povo, da nação, do reino. Inicialmente, a Junta Central promovia um equilíbrio; porém, com as vitórias francesas, um Conselho de Regência foi adotado em 1810.

Apesar das desigualdades entre criollos e peninsulares, os discursos da época evocavam a união dos povos em torno do rei (Guerra, 1994: 201). De acordo com Bushnell (2001), uma historiografia mais tradicional via as Juntas de 1810 como "parte integrante do mesmo processo revolucionário [...] que gerou a Revolução Anglo-Americana de 1776 e a Revolução Francesa de 1789". Entretanto, há uma vertente que analisa os precedentes da ideologia dos próprios criollos no pensamento hispânico tradicional, o qual evocava a ideia de soberania destinada ao povo na ausência do rei (Bushnell, 2001: 132).

Entretanto, discussões em torno do tema da representação nas Cortes de Cádiz confluíram para problemas entre peninsulares e as elites criollas. De acordo com Guerra (1994), as tensões entre colonos e peninsulares se modificaram diante de uma nova forma de fazer 
política a partir da representação, na qual os direitos da América se tornaram alvo de discussão, bem como o vazio de poder. As reclamações envolvendo a igualdade entre colonos e peninsulares eram, naquele momento, pautadas em termos como direito natural e soberania dos povos. 0 reconhecimento das Juntas americanas pelas Cortes foi negado, bem como um pequeno número de representantes das colônias americanas iam para a Junta Central e a Junta de Cádiz, elementos estes que são pedra de toque da compreensão do rechaço às instituições metropolitanas.

Para Manuel Chust (2008), a Constituição de 1812 teve peso considerável, pois trazia uma leitura de soberania nacional, ou seja, não estava vinculada ao rei. A diversidade dos reinos remontava à pluralidade da monarquia hispânica, a qual passava a dar lugar à nação naquele novo contexto. Esta constituição teve impactos importantes tanto na Espanha quanto na América, pois trazia propostas de reformas liberais, conferindo a ampliação da participação política, ainda que as elites tivessem maior projeção no processo (Mader; Pamplona, 2007: 10-12).

Em estudos recentes, as revoluções de independência na América espanhola e os problemas metropolitanos fizeram parte de um mesmo contexto que envolveu a chegada da Modernidade numa monarquia de Antigo Regime que desembocou na desagregação do Império Espanhol (Neves, 2010; Guerra, 1994). Portanto, o processo de independência da América hispânica está relacionado diretamente com a chegada de Napoleão Bonaparte à Espanha e a consequente abdicação de Fernando VII. Ademais, podemos sinalizar que no período ocorreu uma mudança ideológica, na qual os efeitos da Revolução Francesa (1789) serviram de substrato ideológico que não poderia enveredar para a radicalização. 0 governo deveria ser fundado em ideias revolucionárias, "mas estável e respeitoso da lei e da liberdade" (ibidem: 211). Além disso, o impacto das ideias francesas foi variável no conjunto do Império Espanhol, sendo difícil avaliá-lo em sua totalidade (Martínez, 2008: 63).

Com a decisão das Cortes de Cádiz de tornar a nação espanhola um Estado unitário e, anos depois, com a retomada do poder por Fernando VII, os membros da elite criolla passaram a pensar sobre a independência, ainda que dentro de uma concepção moderada de governo (Neves, 2010: 11). Nesse sentido, os cabildos tiveram peso importante na vida política da América naqueles anos, na qual as lutas pela independência marcaram mudanças em relação à América e sua identidade. Partindo das Juntas, os movimentos da elite criolla se transformaram em independência, e eles nutriam suas ideias com base em farta contribuição ideológica. Tais ideias poderiam vir desde a Revolução Francesa ou a partir da própria tradição hispânica do período medieval, que trazia um arcabouço teórico em que a ideia de soberania era oriunda do povo, essencial para os acontecimentos inaugurados em 1810 (Martínez, 2008: 74). 
Assistimos ao gradual processo de construção de identidades opostas: o espanhol e o americano como forma de legitimar as lutas políticas, sobretudo a partir da Restauração. As ações do rei, pautadas sobretudo na violência, desencadearam uma série de reações de uma minoria que almejava a independência (Mäder; Pamplona, 2007: 13). Por conseguinte, percebemos uma quebra nas relações com o rei, que inicialmente os colonos juraram proteger, passando a uma luta pela emancipação política (Guerra, 1994: 217-219).

Para os fins deste texto, procuramos tratar do processo de independência e o consequente desmantelamento do Império Espanhol, tendo como enfoque o Rio da Prata. Procuraremos mostrar as possibilidades de liberdade dos escravos, expressas muitas vezes em resgates e/ou fugas de seus amos com o intuito de servir à defesa da pátria contra os espanhóis. Além disso, veremos como este processo impactou na manutenção da escravidão em terras portuguesas e as reclamações envolvendo o precedente aberto pelo decreto de 4 de fevereiro de 1813, no qual os negros eram livres apenas pelo fato de haverem pisado o solo das recém-criadas Províncias Unidas do Rio da Prata.

\section{A SINUOSA POLÍTICA: OS CAMINHOS ATÉ A INDEPENDÊNCIA DO PRATA}

2 2 De maio de 1810. Naquele dia, um cabildo abierto foi realizado em Buenos Aires para decidir os rumos daquele pedaço do Império Espanhol diante da vacância do trono e da instauração de um Conselho de Regência na Espanha sob domínio francês. 0 vice-rei, Baltazar de Cisneros, chegado àquela praça em 1809 para substituir o vice-rei interino Santiago de Liniers, foi deposto pela pressão das autoridades criollas frente aos líderes do cabildo nos dias seguintes. Esta instituição colonial tinha, a partir daquele momento, a responsabilidade de tutelar os direitos do rei Fernando VII por meio de uma Junta de Governo (Goldman; Tervanasio, 2010: 58). Assim, se iniciava o processo de crise política e de um campo de possibilidades que culminaria na independência das repúblicas hispano-americanas.

Esta Junta Governativa era composta por nove membros, dentre os quais assumia a liderança o chefe das milícias, Cornelio de Saavedra. Este deveria representar os direitos do rei Fernando VII em nome da legitimidade de seu governo frente ao representante francês na Espanha, José Bonaparte. Tal estado de coisas duraria enquanto perdurasse o "cativeiro" de Fernando VII, em nome da soberania dos povos. Em outras palavras, da concepção de que 0 poder emanava do povo, expressa em eventos como a Revolução Francesa (1789-1799), a Revolução Americana (1776) e a filosofia iluminista de meados do século XVIII. 
Com a formação destas juntas governativas nas colônias, muitas de suas ações dependeriam tanto dos caminhos tomados pela metrópole quanto das peculiaridades do espaço variado que compunha o Império Espanhol. Em relação à metrópole, a Junta de Cádiz não jurou fidelidade à Regência instituída e, diante da fragilidade da situação, a junta convocou as Cortes Gerais para decidir os rumos a serem tomados tanto pela Espanha quanto por suas colônias. As Cortes teriam representantes peninsulares e coloniais, mas a representação destes últimos era consideravelmente menor do que a dos primeiros. De acordo com Marcela Tervanasio e Noemí Goldman (2010), as diferenciações na representatividade colonial e metropolitana nas Cortes provocaram sérias frações de interesses dentro das elites coloniais, o que, por sua vez levou a Junta de Buenos Aires a não participar da reunião das Cortes.

Nesse sentido, havia um duplo caminho a ser seguido pelas colônias americanas: o caminho daqueles que se dirigiram às Cortes e o caminho daqueles que resolveram seguir uma postura autônoma, sem necessariamente influir na independência política. Em Buenos Aires, foram emitidas circulares enviadas às várias cidades do interior a fim de realizar convocações para eleger cabildos abiertos e enviar uma representação a Cádiz. Contudo, nem todas as áreas subordinadas À capital do Vice-Reino responderam de maneira positiva a esta convocação. Regiões como o Paraguai adotaram uma postura autônoma em relação a Buenos Aires, ao passo que Montevidéu se manteve como foco dos espanhóis realistas por muitos anos.

As ambiguidades suscitadas por este processo culminaram numa crise interna na Junta a ser enviada a Cádiz. A fidelidade a um rei mantido preso, bem como as instituições que erigiam a colônia sem poder promover mudanças de cunho político-institucional passaram a ser um incômodo. E isso refletia diretamente nas propostas de representação pensadas no seio deste grupo, em que formular uma Constituição soava radical para aqueles que preferiam manter a Junta Governativa sem romper definitivamente com as Cortes de Cádiz. ${ }^{1}$ A chamada Junta Grande, criada a partir de 1811, passou a lidar com problemas de ordem política na medida em que tinha o direito à soberania, mas se encontrava atada para pensar em caminhos e possibilidades diante de um contexto internacional cambiante.

Nesse ínterim, as limitações estabelecidas pelo próprio estatuto colonial acarretaram numa oposição entre Buenos Aires, de caráter mais centralista, e várias cidades que passaram a ver numa proposta autônoma um caminho possível. Algumas cidades passaram a pensar na autonomia pautadas na ideia da soberania emanada dos povos e com base nos seus respectivos cabildos. Desta maneira, muitas cidades subordinadas à capital do Vice-Reino do Prata passaram a postular uma ideia de que uma proposta de autogoverno seria revertida, também, numa proposta de maior participação ante ao governo da capital. A instabilidade 
política daqueles anos se refletiu na dissolução da Junta Grande e na consequente criação de um Triunvirato para governar as então Províncias Unidas do Rio da Prata. A postura moderada do Triunvirato no ano de 1812 suscitou uma série de oposições que exigiam uma postura mais radical por parte do governo colonial, representado pelos cabildos, frente aos espanhóis.

Internamente, o quadro político platino era complexo, marcado por conflitos internos entre os membros das elites criollas. No âmbito externo, a situação também era indefinida. $A$ Constituição de 1812, resultado da reunião dos deputados metropolitanos e coloniais escoIhidos desde 1810, era caracterizada como liberal; contudo, restringia bastante o quadro de alternativas: cabia às pessoas fazer parte daquele novo modelo de país pensado para os dois lados do Atlântico ou não. Buenos Aires acabou se negando a participar deste novo modelo, e isto significava tornar-se um rebelde frente a um grupo "espanhol" oposto a um grupo "americano". Novas identidades acabariam surgindo no decorrer deste processo, sobretudo pelas desigualdades suscitadas entre os vindos da metrópole e aqueles considerados colonos.

0 ano de 1812 marcou uma mudança de rumos nas políticas hispana e americana, na qual a mediação inglesa para promover uma coexistência nas representações tanto da colônia quanto da metrópole, em caráter de igualdade mediante certo grau de autonomia local, não surtiu efeito positivo. 0 caráter provisório instaurado desde 1810 em nome da lealdade ao rei começava a ruir, e era necessário estabelecer um novo rumo político para a região platina. Para tal intento, convocar uma Assembleia Constituinte que representasse todos os povos era fundamental, e isto foi feito pelo Segundo Triunvirato, de características mais radicais, ao postular as ideias de emancipação e de independência.

Assim, houve a reunião conhecida como a Assembleia do Ano XIII, considerado o momento mais radical da revolução no Prata. Como resultados desta assembleia, ficou estabelecida a liberdade de imprensa, a extinção de tributos dos indígenas, tais como a mita e a encomienda, o fim dos títulos de nobreza e a liberdade de ventre às escravas. Mas, do ponto de vista simbólico, as relações entre Espanha e Buenos Aires estavam estremecidas, e isto se expressa pela supressão do juramento de fidelidade ao rei, Fernando VII. A partir daquele momento, os deputados e autoridades coloniais deveriam fazer seu juramento à "nação", a qual não sabiam ainda como definir (Pimenta, 2002).

A partir de 1814, outros ventos passaram a circular nas colônias espanholas, dadas as crescentes derrotas de Napoleão, iniciadas em 1812. 0 retorno de Fernando VII ao poder, bem como a propagação de um clima mais conservador nas estruturas políticas europeias, repercutiu na dinâmica interna das colônias hispânicas - as quais também estavam convulsionadas internamente. Ao passo que Fernando VII procurava reaver o domínio de suas colônias, 
investindo militarmente para conter as regiões rebeldes e os liberais concentrados nas Cortes de Cádiz, havia conflitos entre espanhóis e locais, liderados por membros da elite criolla, em favor da autonomia frente ao absolutismo.

No Rio da Prata especificamente, além das disputas envolvendo as tropas espanholas, havia o confronto envolvendo José Gervasio Artigas, representante da Banda Oriental do Uruguai, e as autoridades de Buenos Aires. Tal confronto colocava em evidência novos projetos de governo para aquelas paragens. A concepção de Artigas para a formação de um governo confederado, em que as províncias poderiam usufruir de maior autonomia e autogoverno frente ao Poder Central, representado por Buenos Aires, constituía um problema latente nos caminhos políticos pensados no Prata. É importante salientar que em diversos momentos as populações oscilaram entre a simples autonomia, a união com os governos centrais, e as propostas confederadas de Artigas (Goldman; Tervanasio, 2010: 57). Estas últimas propostas, por sua vez, mobilizaram índios e negros nas paragens do Prata tanto pela luta contra a dominação espanhola quanto pelos conflitos envolvendo a política a ser implementada no Prata.

A partir de 1810, percebemos um processo de quebra das estruturas político-sociais que pautavam o chamado pacto colonial. À luz dos acontecimentos no Velho Mundo, no qual a fragilidade da monarquia espanhola ficou clara mediante a expansão napoleônica, abriu-se caminho para os processos de emancipação nas colônias americanas. Por outro lado, o Brasil assistia ao reforço da monarquia com a vinda da Corte portuguesa, em 1808, a qual, mesmo com seu processo de independência. manteve o governo monárquico e a escravidão (Pimenta, 2002).

No Congresso de Tucumán, em 9 de julho de 1816, a proclamação da independência das então Províncias Unidas do Rio da Prata contribuiu para que a construção da ideia de nação estivesse vinculada ao Río de la Plata. Este aparecia em associação com o Estado, 0 Congresso, a Constituição, e a forma de governo instituída. A soberania pensada para este novo regime de poder, advinda de ideias das Revoluções Francesa e Americana, concebem um tipo de relação entre os representantes e seus representados por meio de um contrato. Tal concepção sustentava a formação de um Estado unitário em oposição à defesa de uma série de hegemonias existentes no vice-reinado. Nesse ínterim, a coexistência do cabildo como um representante das cidades frente a assembleias e aos poderes centrais - os quais pleiteavam um poder nacional - pautaram as indefinições políticas dos primeiros anos revolucionários. 


\section{ESCRAVOS EM GUERRA: BATALHÕES EM NOME DA PÁTRIA}

"[...] piensa valerse de los negros y mulatos esclavos de los españoles, dándoles libertad con tal de que se hagan soldados y ciertamente ésta es mucha mejor milicia que la del país." (Baltazar de (isneros, 1810) $)^{2}$

Durante muito tempo, o papel das populações negras nas Américas foi interpretado como parte do processo de colonização europeia, no qual a benignidade do sistema escravista transparecia em muitas das interpretações correntes sobre o mundo colonial e independente. A historiografia americana inspirou-se nos trabalhos de Frank Tannembaum (1946) sobre os Estados Unidos e as diferenciações entre os sistemas escravistas desenvolvidos nas Américas, em que o papel das leis era pedra de toque para a compreensão do mundo dos escravos e seu papel naquelas sociedades. No caso da historiografia brasileira, o trabalho de Gilberto Freyre (1933) foi fundamental para a difusão de uma visão benevolente do sistema escravista na América lusitana - alcunhado de "democracia racial" - em contraposição ao mundo colonial anglo-francês. As comparações são elemento metodológico importante para a execução de um modelo mais amplo de História. Seguindo as ideias Tannembaum, Herbert Klein e Cláudio Véliz se preocuparam com as comparações no âmbito das leis e das instituições nas sociedades ibéricas, tendo como norteadores as colônias do Império Britânico (Armitage, 2004: 17-18).

Nos anos 1980, mudanças no modo de fazer História deram lugar a outras interpretações sobre o passado. De análises com um viés quantitativo, passamos a uma abordagem onomástica dos grupos subalternos na qual, segundo Secreto (2016: 443), era possível trabalhar "a subjetividade do vivido, combinando micro-história com história social, ou história da cultura com micro-história". Nesta linha de raciocínio, a escravidão passou a ser estudada a partir das concepções de liberdade, e os historiadores buscavam nas fontes existentes as ações e possibilidades do escravo na condição de protagonista nas sociedades construídas nas paragens atlânticas. Este protagonismo do escravo passou a ser alvo de inquietação dos historiadores, e uma série de trabalhos envolvendo a família, as relações sociais, a cultura, a religiosidade, a resistência e a justiça foram publicados, dando uma nova face aos estudos sobre a escravidão (Schwartz, 2009: 190-192).

A produção historiográfica sobre a escravidão no Rio da Prata despontou a partir dos anos 1980 com temas e problemas da História Econômica e Social (Socolow, 1984). Alguns autores ressaltaram aspectos importantes da presença negra na América hispânica colonial e o papel desempenhado por esses agentes em questões sociais, econômicas e culturais do estuário platino, proporcionando releituras de um passado histórico branco e eu- 
ropeu a partir dos chamados grupos subalternos (Andrews, 1989; Johnson, 1976: 333-348; Studer, 1984). No que tange a Argentina colonial e independente, um processo de exclusão das populações negras foi realizado para dar lugar à construção de um país branco e europeu nas Américas de inícios do século XX. Um dos argumentos reiterados para tal exclusão e para 0 endosso da tese do desaparecimento das populações negras da capital argentina foi justamente as lutas de independência travadas a partir de 1810 e sua incorporação aos exércitos revolucionários (Andrews, 1989).

Nesta direção, cabe ressaltar que o Exército era uma instituição que aceitava os escravos desde os inícios da colonização hispânica. 0 uso de batalhões formados por morenos, pardos e negros era corriqueiro para as defesas do Império Espanhol (Mallo; Telesca, 2010). Valores como bravura e a defesa do território em nome de Sua Majestade Católica foram acionados por alguns negros com a finalidade de sair da escravidão. No contexto do processo de independência, não foi muito diferente. 0 uso de negros escravizados nas tropas, fossem elas formadas exclusivamente por negros ou lideradas pelas elites criollas - e a liberdade era vista como moeda de troca -, seduziu muitos cativos, ao passo que também desestruturava as bases de domínio estabelecidas por seus senhores. A condição escrava nas guerras de independência ficou fragilizada.

0 vice-rei Cisneros apontava que, embora não desejasse, precisava utilizar a força dos negros para a defesa do Rio da Prata contra as forças espanholas. Uma das medidas adotadas por ele naquele momento foi a libertação de escravos dos espanhóis para compor as forças no campo de batalha. Com a formação da primeira Junta, liderada por Cornelio Saavedra em 1811, os ânimos se exaltaram. Um de seus generais, Rondeau, chegou a Montevidéu - local onde os contrarrevolucionários ou realistas estavam alojados - e prometeu a liberdade aos escravos em troca de seu serviço no Exército. Tal promessa teve repercussão no meio daqueles homens, e muitos se juntaram às tropas revolucionárias. Porém, após algumas negociações com os senhores de Montevidéu, os escravos que foram para os batalhões de Buenos Aires acabaram sendo devolvidos (Bernand, 2010).

Nesta direção, percebemos que a revolução liderada por Buenos Aires culminou num campo de possibilidades aos escravos em que, de um lado, havia o sentido de obtenção da liberdade e, de outro, certo temor construído pelos donos e autoridades a respeito dos escravizados (Chavez, 2009). De acordo com Marta Goldberg (2010), havia distintas formas de ingresso nos batalhões negros no Prata, as quais iam desde doaç̃̃es de senhores em nome da causa revolucionária, o uso de prisioneiros - livres ou não -, até a prática do corso e o resgate. A vontade dos escravos também era levada em consideração, e servia como um dos caminhos 
para a aquisição tanto de homens para as tropas quanto para o fim do cativeiro. A partir de 1813, regimentos próprios de negros escravos foram montados. Os mesmos serviriam à pátria por cinco anos nos exércitos de linha, e obteriam a liberdade quando seu tempo de serviço terminasse (ibidem: 45-49).

0 caso dos resgates é interessante. 0 Estado solicitava aos senhores a entrega de pelo menos um escravo para compor as tropas desde maio de 1813. Desta primeira prerrogativa legal, surgiram outras de acordo com as demandas que apareciam tanto por parte do Estado quanto dos proprietários. Havia uma comissão própria para realizar os resgates, de modo que o senhor deveria entregar o cativo em troca de um valor a ser pago pelo governo - valor este que era irrisório se comparado ao custo do escravo para o senhor. Inicialmente, este programa não sofreu muita resistência por parte dos escravos, o que não se pode dizer dos senhores, ciosos de perderem suas propriedades para o governo e para a guerra (Andrews, 1989: 140).

Diante das manobras realizadas para evitar o envio de escravos às tropas, em dezembro do mesmo ano de 1813 o Estado revolucionário solicitou que os senhores que possuíssem mais de um escravo e não tivessem contribuído à causa oferecessem um escravo para uma listagem a ser feita pela comissão de resgates e, daquele conjunto, seria realizado um sorteio dos que seriam enviados para o Exército. Outros proprietários, entre os quais aqueles que possuíam excedentes, deveriam enviar o nome de um escravo para cada excedente a fim de que fosse realizado o sorteio. Respectivamente, teríamos de cada tipo de proprietário em torno de 15\% e 30\% das tropas (Bernard; Quijada; Schneider, 2000: 127).

Os escravos dos espanhóis eram alvos potenciais destas ações do Estado. 0 caso do médico d. Miguel de Gorman se enquadra no que abordamos anteriormente. Segundo informações, Gorman tinha em seu poder três escravos homens, dos quais nenhum fora enviado ao batalhão de Libertos. 0 médico alegava que Pedro, de 23 anos, era o único que estava a seu serviço. 0 outro, chamado Joaquim, com 24 anos, "hace el espacio de dos meses que lo tiene con papel de venta, aguardando [que de] un día para otro le presente comprador". 0 último, Gregorio, de 9 anos de idade "lo ha tomado fiado a Ermenegildo Echavia, a quien le tiene dado en cuenta de pago una cierta parte en alquileres". ${ }^{3}$ Dadas estas informações, que evidenciam a pluralidade das relações de trabalho estabelecidas nas cidades hispano-crioulas, o médico achou que seu caso constituía uma exceção ao bando que dispunha sobre o tema do resgate de escravos.

Em 1815, o médico notificava as autoridades de Buenos Aires a fuga de Gregorio, o qual deveria ter entre 11 e 12 anos de idade. Segundo o médico, o escravo sentou praça de 
soldado no Regimento de número 10. Solicitava que, com base na justiça, "se me devuelva y entregue dicho mulato; pues carezco de su servicio", posto que o médico se encontrava de cama. Outro argumento usado pelo médico foi o de que o nome de Gregorio não estava incluído no bando publicado "para q. los Europeos Españoles entreguense sus esclavos para el servicio de la Patria". ${ }^{4}$ Pelas leis, escravos menores de 16 anos não deveriam incorporar as tropas; contudo, podemos perceber que esta norma não fora levada em consideração. Miguel Pestana, de 10 anos, e Antonio Molera, de 8, foram enviados ao serviço das armas e tiveram como resgate 140 e 100 pesos, respectivamente. Possivelmente estes menores foram usados como tambores nas tropas. ${ }^{5}$

Outro caso que tinha como precedente o bando de 1813 foi o da senhora dona Juana Azevedo, esposa de d. Juan Lopes. A mesma afirmou que, devido ao último bando expedido, pelo qual os europeus deveriam entregar os escravos que tivessem idades entre 16 a 30 anos, seu marido entregou o único escravo que tinha, chamado Juan. Sua súplica consistia basicamente em "entregar otro Negro à satisfaccion de la Comisión q. estoy pronta a comprar $p^{a}$ rescatar al expresado negro Juan". ${ }^{6}$ Tal troca deveria ser realizada posto que houve muito empenho em ensinar ao escravo o ofício de seu marido para subsistência e sustento da família. Escravos com alguma especialização eram valiosos para seus senhores, o que explicava o pleito de dona Juana na medida em que a sobrevivência de sua família estava em jogo caso o escravo não fosse devolvido.

D. Juan Batista Mujica apresentou uma solicitação semelhante. Ele havia entregado dois de seis escravos que tinha sob seu domínio quando da publicação do bando. Um deles foi considerado inapto para o serviço militar; e aqueles que foram selecionados para substituir o escravo arrumaram outros meios para fugir deste serviço. Com isso, Mujica teve de apresentar todos os seus criados à comissão de resgate, e Antonio foi escolhido. Era ferreiro de ofício, "[...] y el único que dirige y trabaja en la Herrería". Por Antonio, Mujica ofereceu dinheiro para substitui-lo, o que lhe foi negado; propôs comprar um escravo que pudesse satisfazer a comissão e realizar uma troca, o que foi aceito. Antonio foi trocado por um negro de 18 anos de idade, "sano, robusto, y q. llena los deseos de la Comisión misma; pero se excusa a aceptarlo a pretexto de hallarse filiado el Antonio". ${ }^{8}$ Mujica se sentia lesado em seus direitos e interpretava o fato:

Sobre todo la dificultad, parece que está reducida a dar de baja un soldado que debió ser excusado legitimam[en]te, y yo reduzco mi solicitud á q. V.E. se sirva mandar que se me admita el que presento en su remplazo [...] y se me devuelva el Antonio." 9 
Dias depois, o escravo Antonio foi devolvido ao seu senhor, ${ }^{10}$ o que mostra também a necessidade de o governo arbitrar a questão dos escravos arrolados para a guerra de modo a não afetar os interesses diretos de seus donos. Os sorteios envolvendo escravos de proprietários espanhóis poderiam suscitar uma série de problemas nos quais o direito à propriedade acabava sendo um princípio norteador das ações contrárias à comissão de resgate. Substituir os inválidos, bem como escravos com algum tipo de especialização, representava despesas aos senhores, seja para enviar outro escravo e realizar uma troca, seja para sustentar o que fora enviado ao sorteio e não aproveitado pela comissão. Desta forma, de uma inicial corrente de ânimo em torno da causa revolucionária, os resgates passaram a ser questionados por meio de petições e pedidos de abonos ao governo, motivados pela dependência econômica dos senhores em relação aos escravos arrolados nos sorteios (Andrews, 1989: 140).

Outro elemento importante era o valor do resgate. Um exemplo é o caso do escravo Gerônimo Balbino, o qual foi reclamado por seu senhor "ó su importe por su tasación [...] que al poco tiempo de su compra se me huyó". Em resposta, datada de 23 de novembro, afirmavam que não poderiam se desfazer do escravo por "no tener facultades para reponer el q. reclama", podendo ceder em seu valor em duzentos pesos, "rebajando de su total valor cincuenta pesos [,] inclusa la deuda de Alcabala". ${ }^{11}$ Nesse caso, o senhor tinha prejuízo na medida em que gastara um determinado valor e receberia em torno de 150 pesos pelo escravo. Se considerarmos que, em média, o proprietário poderia receber 200 pesos pelo resgate; os mesmos tinham prejuízos consideráveis, pois o valor dado pelo Estado era muito menor do que o escravo valia (Bernand; Quijada; Schneider, 2000: 127).

Além das discussões em torno do preço ou da devolução do escravo ao seu proprietário, havia também a questão dos inválidos e a constante ameaça de fugas. Aqueles considerados incapacitados pela comissão de resgates deveriam ser devolvidos aos seus senhores e, por conseguinte, substituídos por outros do mesmo proprietário. Em 1814, houve a notificação da fuga de dois escravos, chamados José e Gordiano, fugidos da Vila do Rosário, de propriedade de d. José Diaz. ${ }^{12}$ Os escravos foram conduzidos ao seu dono pelo tropeiro d. José Antonio Villa, o que se explica pelo fato de eles serem considerados inúteis no Batalhão número $8 .{ }^{13}$ Estes escravos deveriam ser substituídos por seu senhor no serviço das armas. No entanto, o referido tropeiro deveria conduzir o Batalhão número 9 e, por isso, deixou os escravos aos cuidados do juiz territorial da Vila dos Ranchos. ${ }^{14}$ De acordo com o juiz de Santa Fé, Pedro Ferreira, o tropeiro afirmou que os referidos escravos fugiram das carretas quando ele chegou a Buenos Aires e solicitou aos seus superiores que fossem capturados. ${ }^{15}$ No caso arrolado, a mobilidade dos escravos no percurso até chegar a seu senhor em Rosário acabava por auxi- 
liá-los no empreendimento da fuga, pois podiam se misturar a outros de cor negra viventes nas cidades platinas.

Na fronteira de Buenos Aires, esta possibilidade também era evidente. Dona Maria Josefa Chaves, viúva do tenente-coronel d. Manuel Fernandes, do Regimento de Blandengues, disse que um negro chamado Santiago, com aproximadamente 20 anos de idade, são e sem vícios conhecidos, havia fugido "de mi lado en el partido de Chascumús". ${ }^{16}$ Informou também que o escravo havia se apresentado no serviço militar e que descobriu tal informação por casualidade, visto que alguns membros do Batalhão de Aguerridos estavam realizando exercícios na praça principal da cidade. Ao saber disso,

"Inmediatamente reclamé a mi Esclavo, y sobre ello hablé con el Comandante del Batallón, quien impuesto a mi reclamación, me contestó q. hacía pocos dias q. habia sido aprendido como vago y conducido como tal desde las Conchas donde corría por libre; y bajo este concepto filiándola. El esclavo confesó en el acto ser yo su ama pero con en el mismo acto manifestase alguna inclinación al ejercicio militar quedé en recurrir a V.E. pa q. sirviéndose disponer y me entregara su importancia de un modo efectivo, pudiese continuar en el mismo servicio de las armas; o si no me fuese entregado el Esclavo conservándose entre tanto como detenido"17

Provavelmente Santiago sabia das notícias envolvendo o recrutamento de homens de cor e, consequentemente, a obtenção da liberdade em contrapartida. Possivelmente fugira para alcançar tal objetivo. Por outro lado, o escravo, considerado um homem vago pelas autoridades militares da região, foi visto como um alvo fácil para o recrutamento. A resposta, dada em 3 de janeiro de 1818, colocava em evidência o direito de a senhora requerer o escravo, devendo assim deliberar para que o resgate fosse realizado. Portanto, o direito à propriedade pesava tanto quanto o direito à liberdade. Por outro lado, pode se afirmar que muitos negros conseguiram obter certo prestígio e ascensão no serviço das armas, tornando-se heróis daqueles tempos (Andrews, 1989).

Embora houvesse dificuldades em torno do resgate dos escravos, esta era uma forma de obter um número expressivo de homens para compor as tropas revolucionárias. Nesse sentido, o projeto era positivo. Defender a pátria era fundamental, ainda que uma das moedas de troca para isto fosse a liberdade dos escravos. As guerras pela independência no Rio da Prata erodiam as bases da escravidão, embora houvesse resistências por parte dos senhores. Viajantes da época, como Emeric Vidal, observavam que este projeto de resgates era benéfico, expressão da benignidade porteña para o fim da escravidão. Contudo, este não levava em consideração as dificuldades inerentes ao processo de obtenção da liberdade: a necessidade de servir por mais um ou dois anos no campo de batalha, as intempéries e a própria sobrevivência dos cativos para usufruir de tal liberdade (idem). 
A abolição não foi fruto imediato da independência, porém a gradual extinção do trabaIho escravo foi uma das consequências de tal processo. De acordo com Maria Eugenia Chavez (2009), é importante analisarmos os significados distintos que a palavra liberdade assumiu naquele momento como forma de compreender melhor as ações dos escravos no período das guerras de independência. A liberdade poderia estar condicionada à guerra, ou ser fruto do costume ou mesmo ser uma prerrogativa alcançada com o uso das leis e das instituições. Ademais, a concepção de que o serviço militar poderia libertar os cativos atraiu, por um lado, pessoas escravizadas de várias paragens do Prata e, por outro lado, escravos vindos de suas fronteiras, em especial do Brasil. A promessa de liberdade no solo das Províncias Unidas, associada ao contexto de guerras pela defesa da pátria contra o inimigo espanhol, não envolveu apenas os interesses dos senhores da futura Argentina, como também o de senhores luso-brasileiros viventes no Rio Grande do Sul, os quais assistiam aos acontecimentos do Prata com preocupações que esbarraram também no âmbito do relacionamento diplomático daqueles anos.

0 decreto de 4 de fevereiro de 1813 provocou impactos nas escravarias da fronteira meridional: "La Asemblea General ordena que todos los Esclavos de países estrangeros, que de cualquier modo se introduzcan desde este día en adelante, queden libres por solo el hecho de pisar el territorio de las Provincias Unidas." 18

Entre os anos de 1810 e 1812, pode se afirmar que as fugas escravas do Rio Grande rumo ao Rio da Prata foram pouco expressivas. 0 mesmo não se poderá dizer dos anos seguintes. 0 decorrer dos processos de independência das futuras repúblicas hispano-americanas gerou uma série de problemas tanto internos quanto externos. Se, por um lado, havia o crescente exagero das autoridades portuguesas com relação à movimentação de escravos pela fronteira meridional, por outro, havia uma série de objetivos geopolíticos envolvidos, entre os quais a consolidação de uma política de intervenção no Prata e assegurar uma determinada territorialidade que integrasse o Amazonas ao Prata no conjunto da colônia luso-brasileira e, posteriormente, o Império do Brasil.

Quando da Revolução de Maio, as autoridades de Montevidéu permitiram uma primeira intervenção portuguesa no Prata, em 1811. Tal intervenção tinha duas razões: a primeira delas é sua posição estratégica, numa das margens do estuário platino. A segunda consistia na riqueza da Banda Oriental, a pecuária (Ferreira, 2014: 325). A união de Artigas com Buenos Aires contra os espanhóis de Montevidéu culminou no envio de uma "força pacificadora" por d. João VI. A pressão envolvendo portugueses e portenhos permitiu a assinatura, em 1812, de um armistício entre Buenos Aires e Portugal. Este armistício ficou conhecido como 
Tratado Rademaker-Herrera. De acordo com Gabriel Aladrén (2012: 256-257), se por um lado o armistício tinha por premissa a retirada das tropas lusitanas de Montevidéu, por outro, a guerra entre os interesses centralistas de Buenos Aires e as propostas confederadas de Artigas mantinha o clima de instabilidade na região, promovendo problemas de ordem internacional que ameaçavam os interesses lusitanos naquelas fronteiras.

Tanto o governo português quanto o de Buenos Aires acordaram na não invasão dos territórios a fim de esperar o final do conflito para solucionar questões relativas às terras dos campos neutrais e da Lagoa Mirim. As questões sobre o que fazer com estas paragens e outras querelas envolvendo limites deveriam ser resolvidas sob o arbítrio das Majestades Católica e Fidelíssima quando a paz se restabelecesse. Porém, se a questão territorial era deixada para outro momento, a circulação das pessoas pela fronteira deveria ser solucionada. 0 conde de Linhares escrevia, entre outros pontos considerados relevantes aos portugueses para a negociação do armistício, a recíproca libertação de portugueses e espanhóis aprisionados nos territórios espanhol e português, os negociantes portugueses "presos em Buenos Aires [...] assim como entregarão todos os Escravos fugidos a Portugueses empregados no Exército de Buenos Aires aos quais Rondeau deu Cartas de Liberdade ou de d'Alforria, e que montão a mais de oitocentos". ${ }^{19}$

Não sabemos se o general Rondeau chegou a libertar esse número de oitocentos escravos ou se consistia num certo exagero do conde de Linhares para solucionar mais rapidamente a questão. 0 que podemos depreender é que, naquele momento, os bens e propriedades dos portugueses presos em Buenos Aires ou que perderam seus escravos pelas ações no Prata deveriam ser assegurados por seu governo, representado na figura de d. João VI, que apreciava 0 andamento das negociações. Portanto, o problema das demarcações de fronteira estava em segundo plano, ao passo que os escravos fugitivos consistiam numa questão de primeira ordem para as autoridades lusitanas.

A assembleia do ano XIII foi fundamental para o amadurecimento dos projetos de independência, bem como apontava para os possíveis caminhos da emancipação política. Diante da negativa à proposta artiguista, os conflitos envolvendo, de um lado, a Banda Oriental e outras províncias e, de outro, Buenos Aires, prevaleciam. Naquele mesmo ano, foi assinada uma lei que previa a liberdade de ventre das escravas, e um decreto em que se concedia a liberdade aos escravos pelo simples fato de haverem pisado o território das Províncias Unidas do Prata. Por isso, o aumento das fugas escravas do Rio Grande para a fronteira do Prata tornou-se um assunto recorrente entre as autoridades diplomáticas. De acordo com o conde de Galvêas, este fato novo causava inquietações ao ânimo de Sua Alteza Real, o príncipe regente. Seguindo 
seu raciocínio, tal decreto poderia "[...] atentar direta e positivamente contra a segurança da Propriedade individual dos vassalos residentes nas Capitanias limítrofes" ${ }^{20}$

Para o conde, isso abalava as relações de amizade e confiança, além da boa-fé entre as duas partes. Para demonstrar isto, colocava em evidência o papel da Convenção de 26 de maio de 1812, ou seja, o armistício que retirou as tropas pacificadoras de Montevidéu. Tal procedimento do governo de Buenos Aires tinha como consequência a "furtiva passagem que começam a fazer os Escravos dos Habitantes da Capitania de São Pedro". ${ }^{21}$ Solicitava, assim, a pronta devolução dos fugitivos, e que diligências fossem realizadas para evitar a continuidade de um "semelhante mal". ${ }^{22}$ Embora os portugueses usassem o armistício como argumento para legitimar seus pedidos de devolução dos escravos, o mesmo princípio não estava inserido na lei. Ou seja, as argumentações traçadas pelo conde de Linhares para o retorno dos escravos não foram aceitas como parte do acordo entre Brasil e Buenos Aires, embora, para as autoridades hispano-crioulas, ficasse evidente que o "problema dos escravos" seria solucionado tão logo terminasse a guerra. Por isso não se estranha certa antipatia das autoridades luso-brasileiras com relação a este acordo.

Pode se afirmar que o decreto de 1813 trouxe a continuidade de traços coloniais, tais como a manutenção do derecho de asilo espanhol, que desde as Reais Cédulas do século XVIII tratava da libertação de escravos oriundos de colônias estrangeiras. Esta continuidade pode ser justificada pelas agruras da guerra e a constante necessidade de recursos e homens, sendo a liberdade um meio para atrair pessoas escravizadas ao Prata. 0 decreto também reafirmava uma série de dificuldades diplomáticas envolvendo o Brasil, pois o aumento das fugas escravas poderia ser indicativo de perdas de homens leais ao reino português. Isto fica mais claro na medida em que as constantes reclamações portuguesas no decorrer daquele ano eram pautadas no decoro "de seus direitos de soberania, e utilidade de seus vassalos". ${ }^{23}$ Nesse ínterim, manter a propriedade escrava dos súditos do Rio Grande do Sul era fundamental para a garantia daquele território frente aos conflitos envolvendo Buenos Aires e a Banda Oriental.

Os efeitos deste decreto e do armistício foram negativos aos interesses dos senhores luso-brasileiros. Suas desvantagens eram expressas em narrativas veiculadas pela imprensa daqueles tempos. 0 Correio Braziliense, cujo editor era Hipólito José da Costa, analisava o impacto das investidas de Artigas no conjunto das fronteiras luso-brasileiras. Segundo o mesmo editor "Tendo Montevidéu caído nas mãos dos Insurgentes, logo eles começaram a infestar as fronteiras do Brasil, e a convidar os Índios e os Negros que se revoltassem". ${ }^{24}$

A imprensa, importante veículo de circulação de notícias sobre o andamento dos rumos políticos do Prata, foi fundamental para a formação de novas identidades políticas, espelhan- 
do de um lado uma noção de unidade luso-brasileira em relação à anarquia e às imprecisões políticas vividas no Império Espanhol. Isto seria crucial para a formação de identidades políticas e a conceituação de temas como Estado, nação, república, e governo. Este processo, analisado por João Paulo Pimenta mediante periódicos do período, nos evidencia uma série de problemas em torno da legitimidade do poder e os caminhos políticos pensados tanto pelos líderes dos processos de independência quanto contidos nas intenções e expectativas dos editores de jornais (Pimenta, 2002).

Ademais, no que diz respeito ao decreto de 1813 , podemos pensar seus efeitos pelo menos em duas frentes: uma envolvendo as relações entre os lusitanos e Buenos Aires, e outra envolvendo os mesmos lusitanos e Artigas, o qual se esquivava das instruções para a devolução dos escravos, alegando que as mesmas não eram de sua responsabilidade, na medida em que seu "mando en esta Provincia es puramente militar, y asuntos de esta classe no son de mi resorte". ${ }^{25} \mathrm{~A}$ passagem dos escravos para territórios hispânicos continuava, o que causava alarde às autoridades diplomáticas e aos senhores de escravos do Rio Grande de São Pedro, e mostrava tanto a insegurança das fronteiras quanto a ameaça à propriedade.

Alguns casos são elucidativos dos problemas envolvendo os portugueses e Artigas na Banda Oriental. Suas ações na campanha contra Buenos Aires eram objeto de atração para os escravos, sobretudo pelas promessas de liberdade em torno do serviço militar. Em novembro de 1813, Pedro Fagundes de Oliveira remetia uma reclamação ao governo em que dizia que oito escravos de sua propriedade passaram "além do Rio Negro [...] fugidos" e enviava a filiação dos mesmos para que fossem " [...] remetidos, por via do meu bastante Procurador, para cujo fim o tenho constituído, e lhe abdicado todos os meus poderes sobre semelhante objeto". ${ }^{26}$

Além disso, Fagundes assegurava que reclamou os escravos a Artigas, presumindo que este tinha autoridade sobre a causa reclamada, mas o dito general "[...] me faz ver pelo Seu horroroso ofício, q. não é de sua jurisdição deliberar sobre semelhantes assuntos". ${ }^{27}$ As escusas de Artigas para arbitrar a questão dos escravos eram, para as autoridades e senhores do Rio Grande, uma afronta. Já para os escravos, significavam uma forma de proteção e asilo frente ao cativeiro, o que garantia sua mobilidade pelos territórios fronteiriços. Nesse ínterim, fugas individuais e coletivas ocorreram nas paragens do Prata associadas tanto ao contexto da guerra quanto à possibilidade de aquisição da liberdade - o que corrobora o protagonismo dos negros tanto nas lutas pela independência política quanto pela sua emancipação individual. Dias depois, o mesmo Pedro Fagundes noticiava a Francisco Xavier Curado o andamento das tropas de Artigas na fronteira, e contava que dois espanhóis, chamados Francisco de Oli- 
veira e Lourenço, estavam mancomunados para fugir com todos os seus escravos e os de seus vizinhos, e que no dia combinado para o embuste,

[...] prendi uns, e fugiram outros, de sorte que pelas diligências que fiz foi preso o dito Oliveira, em um mato com dois Escravos meus, e uma Escrava que já trazia de Cerro Largo, tendo então já feito prender o outro Espanhol seu companheiro, os quais remeti à prisão da Vila do Rio Grande. ${ }^{28}$

Ao passo que as negociações com Artigas se complicavam na Banda Oriental, em Buenos Aires os interesses lusitanos na devolução dos escravos seriam obtidos. Consta que em 18140 governo revolucionário ordenou que todo escravo fugido do Brasil deveria ser devolvido a seu dono (Andrews, 1989; Blackburn, 2002). Em Montevidéu, esta medida foi tomada em agosto do mesmo ano. De acordo com o documento, ficava determinado que todos os escravos que foram roubados dos vizinhos e se achassem em poder dos apresadores seriam devolvidos a seus donos toda vez que fossem reclamados e tivessem sua propriedade justificada. ${ }^{29}$

Levando em consideração que Montevidéu estava sob o mando dos contrarrevolucionários espanhóis naquele momento, compreendem-se os interesses envolvidos em tal decisão. Com os rumos incertos da política do Prata e a continuidade do cativeiro do rei Fernando VII, a quem se mantinham fiéis pela monarquia, os mesmos mantinham uma aliança com Portugal pela imprevisibilidade dos acontecimentos, em caso de um conflito maior com Artigas e com Buenos Aires. Desde que o proprietário justificasse a propriedade, o escravo era devolvido a seu legítimo senhor ao partir da premissa de que a propriedade valia mais do que a liberdade. Além disso, Artigas controlava as fronteiras, e os escravos fugidos eram incorporados a seu exército. Compreende-se as motivações para a revogação do decreto de 4 de fevereiro de 1813, posto que as tropas inimigas eram engrossadas por batalhões, desfavorecendo tanto Buenos Aires quanto Montevidéu (Aladrén, 2012: 270).

Contudo, as brechas da legislação permitiam a continuidade de um trânsito de escravos pela fronteira justificado pelo seu uso pessoal ou pelas necessidades da guerra. Em Montevidéu, um decreto de novembro de 1814 dizia que os escravos fugidos daquela praça que se encontrassem nas mãos de paisanos e oficiais, os quais mantiveram estes escravos sob seu domínio, deveriam ser imediatamente enviados ao Batalhão de Libertos número 10. Esta medida também era ameaçadora aos portugueses, pois escravos de sua propriedade poderiam estar a serviço de algum oficial ou paisano no Prata. ${ }^{30}$ Por outro lado, algumas famílias em Buenos Aires incorreram a permissões especiais para trazer escravos para si mesmos. Além disso, escravas grávidas também eram trazidas de outros locais ao Prata para dar à luz filhos que seriam escravos, driblando os efeitos da Lei do Ventre Livre, de 1813. Nesse ínterim, as medidas 
tomadas pelos senhores do Prata para garantir acesso à mão de obra africana prevaleciam frente aos interesses em torno da liberdade dos mesmos (Andrews, 1989: 65). Era mais uma forma de manter o trabalho escravo e, consequentemente, o sistema escravista vigorava na contramão do processo de abolição no Rio da Prata.

No que tange ao conflito, 0 ano de 1814 foi emblemático na medida em que as tropas artiguistas foram derrotadas e precisaram realizar um acordo diante da tomada de Montevidéu pelos portenhos. Os portenhos precisavam derrotar Artigas e conseguir um maior controle sobre a Banda Oriental. Este acordo, pelo qual o líder da Banda Oriental deveria reconhecer o governo das Províncias Unidas, bem como abrir mão de suas pretensões na região de Entre Rios, não durou dois meses. Os conflitos foram retomados, abrindo uma fase de maior radicalização política contra as forças de Buenos Aires. 0 apoio da população da Banda Oriental foi fundamental a este processo (Aladrén, 2012: 274).

Pelo lado lusitano, os registros das reclamações pelos escravos fugitivos continuavam. 0 marquês de Alegrete escreveu em 1815 uma reclamação a Artigas pelos escravos fugitivos do Rio Grande. Como resposta, recebeu:

Cuantos Esclavos han venido de esos Territorios, otros tantos he devuelto al reclamo de sus dueños. Los Morenos que actualmente sirven en mi Ejército son desertados de las Tropas de Buenos Aires: Aquel Gobierno será responsable de su comportación, y no es regular que manteniendo con él la guerra le haga las reclamaciones que V.E. reclama y que adjunto devuelvo. ${ }^{31}$

Podemos perceber que 0 assunto dos escravos fugidos para as terras espanholas continuava a fazer parte do bojo das argumentações portuguesas com Artigas. Nesse sentido, uma questão importante é pensar o impacto ameaçador das campanhas artiguistas na Banda Oriental que, ao passo que atraía os povos indígenas e negros para o confronto, atemorizava portugueses, espanhóis realistas e hispano-crioulos de Buenos Aires. Inicialmente apoiado pela junta de Buenos Aires, Artigas tornou-se, nas palavras de João Paulo Pimenta, um "protagonista de um projeto político próprio" que se opunha a outras concepções políticas em curso.

Em adição a tal aspecto, a ocupação territorial era cada vez mais importante na medida em que tanto para portugueses quanto para realistas o uso dos territórios era imprescindível para a manutenção da soberania e da obediência aos poderes de Sua Majestade o rei Fernando VII. Nesse ínterim, a mola propulsora das intervenções lusitanas foi a ocupação territorial para dar conta de uma ordem em meio ao caos representado pela figura de Artigas. Além da constituição de novas identidades políticas, as intervenções lusitanas também expunham a debilidade das províncias do Império Espanhol, e o caminho pela independência tornou-se 
uma escolha após o retorno de Fernando VII ao poder e sua necessidade de reaver seus vastos domínios na América.

No decorrer das linhas deste artigo, foi possível perceber que a constituição de novas identidades políticas também acarretou a formação de novas territorialidades. Mesmo com a ideia de delimitar as fronteiras, tais tentativas malograram nos conturbados anos da independência política, os quais também culminaram na abolição gradativa da escravidão nas futuras repúblicas hispânicas (Andrews, 1989; Pimenta, 2002: 122). A mudança de categorias analíticas deste período nos evidencia também as mudanças nas concepções de mundo vivenciadas no contexto da crise do mundo colonial. Novas ideias, novos caminhos e expectativas surgiram no decorrer deste processo envolvendo os interesses de diversos grupos sociais. É possível perceber uma maior visibilidade nesse processo na medida em que a soberania, antes oriunda do rei e de sua relação com os súditos, passava a emanar do povo.

Ao passo que no período colonial temas como a ocupação e defesa de um dado território legitimavam a posse da terra, nos primeiros anos do século XIX tal ocupação esteve imbricada em termos mais abrangentes, tais como a relação do indivíduo com a terra, com seus recursos, com as leis e seu impacto na vida cotidiana. Nessa direção, o status jurídico de uma pessoa poderia ser modificado dependendo do local onde estivesse, ponto importante para a compreensão do decreto de 1813 e de seus efeitos numa fronteira conturbada pela guerra (Grinberg, 2007: 267-285).

A questão da liberdade do solo, premissa pensada pelo decreto de 1813, não estava presente apenas no universo dos escravos fugitivos dos senhores do Rio Grande; estava presente também entre os povos indígenas e colonos da América hispânica. Como tal ideia se espraiou, gerando anseios e expectativas a tão distintos grupos, separados pela condição jurídica e social? Por um lado, pensamos que tal processo aconteceu na medida em que a presença da Coroa Espanhola iria, gradativamente, representar um cativeiro que não cabia mais às elites criollas. Por outro lado, a ideia de governar livremente um determinado território passou a atrair indígenas que almejavam ter seus próprios líderes como representantes. Aos negros, fugitivos ou não, a perspectiva da liberdade, fosse ao adentrar o solo das Províncias Unidas do Prata, fosse para compor as forças artiguistas, representava um conjunto de expectativas e possibilidades no decorrer daqueles anos - mesmo com as pressões lusitanas em torno de um tema de difícil arbitragem: a devolução mútua e recíproca de escravos fugitivos da fronteira, 0 que esbarrava nos preceitos de liberdade do cativeiro presentes no ideário político da América espanhola recém-independente. 
A segunda intervenção lusitana, liderada por Carlos Lecor em 1817, esteve diretamente associada ao andamento do processo de independência do Prata. A vitória portuguesa e sua entrada na Banda Oriental culminou numa série de ações que, se por um lado objetivavam manter o acesso lusitano aos recursos daquela região, também pulverizavam as dissidências internas em prol de um interesse em comum. Nesse ínterim, a anexação da Banda Oriental ao território do Brasil, a qual se chamaria província Cisplatina, bem como a consequente derrota do artiguismo, em 1820, contribuíram a constituição de identidades políticas nas quais, se, num primeiro momento, o domínio lusitano era visto como positivo, ele depois passou a ser corolário de inimizades e de novas propostas políticas.

Num contexto belicoso e cambiante, as ações de escravos e seu ir e vir por fronteiras indeterminadas foi aspecto importante para a obtenção de sua liberdade ou mesmo de uma meIhoria de sua condição no seio da escravidão. As possibilidades abertas de luta pela liberdade num contexto de mudanças políticas mais amplas nos remetem à correlação existente entre a liberdade da pátria e a liberdade dos povos, em que a persistência da escravidão era problemática aos novos Estados Nacionais em formação naquele momento, e se transformou num espaço de disputas com o Brasil, onde a escravidão foi mantida até fins do século XIX. Nesse sentido, a relação entre as emancipações políticas, o serviço militar e a alforria aos escravos marcaram os futuros Estados Nacionais, nos quais a participação dos negros como agentes históricos foi fundamental para a instauração de regimes republicanos no Rio da Prata.

\section{NOTAS}

1 Tais ideias eram representadas, respectivamente, por Mariano Moreno e Cornelio Saavedra. Moreno era considerado um radical ao pensar numa constituição, e veiculava suas ideias na Gazeta de Buenos Aires. Saavedra, por sua vez, procurava diminuir a exaltação dos ânimos com uma proposta que mantinha a lealdade ao monarca, sem, contudo, obedecer a Regência e as Cortes de Cádiz.

2 DOCUMENTOS REFERENTES a la insurrección de la ciudad de Buenos Aires en el año 1810. Biblioteca Nacional de Madrid, MS 7.225, f. 3.

3 NOTA DEL Ayudante-Mayor de la Plaza, d. Jorge Robredo. Buenos Aires, 17 de agosto de 1813. Archivo General de la Nación Argentina (Doravante AGNA). Esclavos (Rescate de guerra) - 1813-1817, sala X, 43-6-7.

4 RECLAMACIÓN DE d. Miguel Gorman. Buenos Aires, 14 de noviembre de 1815. AGNA. Esclavos (Rescate de guerra) - 1813-1817, sala X. 43-6-7.

5 RESCATE DE los esclavos Miguel Pestana y Antonio Molera. AGNA. Policia. Libertos. Sala X. 43-6-9.

6 CARTA de Dona Juana Azevedo para el Excmo. Supremo Director de las Provincias Unidas del Río da Prata. Buenos Aires, 23 de febrero de 1815. AGNA. Esclavos (Rescate de guerra) - 1813-1817, sala X, 43-6-7. 
7 REQUERIMIENTO de Juan Batista de Mujica. Buenos Aires, 08 de marzo de 1814. AGN. Esclavos (Rescate de guerra) - 1813-1817, sala X, 43-6-7.

8 Idem.

9 Idem.

10 NOTA SOBRE el esclavo Antonio. Acampamento de Olivos, 10 de marzo de 1814. AGN. Esclavos (Rescate de guerra) - 1813-1817, sala $X, 43-6-7$.

11 RESCATE DEL esclavo Geronimo Balbino. Buenos Aires, 16 de noviembre de 1815. AGN. Esclavos (Rescate de guerra) - 1813-1817, sala X, 43-6-7.

12 RESCATE DE los esclavos José y Gordiano. Córdoba, 09 de octubre de 1814. AGN. Esclavos (Rescate de guerra) - 1813-1817, sala X, 43-6-7.

13 Este batalhão era formado exclusivamente por negros resgatados. Cf. Andrews, 1989.

14 RESCATE DE los esclavos José y Gordiano. Buenos Aires, 22 de agosto de 1814. AGN. Esclavos (Rescate de guerra) - 1813-1817, sala X, 43-6-7.

15 Idem. Rosário, 26 de setembro de 1814.

16 RECLAMO DE Dueña María Josefa Chaves. Buenos Aires, 24 de diciembre de 1817. AGN. Esclavos (Rescate de guerra) - 1813-1817, sala X, 43-6-7.

17 Idem.

18 CÓPIA DO decreto de 4 de fevereiro de 1813. Arquivo Histórico do Itamaraty (doravante AHI). Documentação do Ministério anterior a 1822. Época da independência - Rio da Prata (1812-1816). lata 193, maço 2, pasta 8.

19 CARTA do conde de Linhares para Diego de Sousa. Rio de Janeiro, $1^{\circ}$ de novembro de 1811. Arquivo Nacional do Rio de Janeiro (Doravante ANRJ). Coleção Artigas, tomo 6, p. 255-256.

20 CÓPIA DA carta do conde de Galvêas à Junta Governativa de Buenos Aires. Rio de Janeiro, 03 de novembro de 1813. AHI. Época da independência (1813). Documentação anterior a 1822, lata 193, maço 3, pasta 9.

21 Idem.

22 Idem.

23 CARTA DO governo de S.A.R. o Príncipe Regente a D. Gervasio Posadas, Diretor Supremo das Províncias Unidas. Rio de Janeiro, abril de 1814. AHI. Época da independência (1813). Documentação anterior a 1822, lata 193, maço 2, pasta 11.

24 COSTA, Hipólito José da. Correio Braziliense, ou Armazém literário, v. 18, Londres, p. 652, 1817.

25 CARTA DE Artigas para Pedro Fagundes de Oliveira. Quartel General en Salto Chico Occidental, 11 de octubre o de 1813. ANRJ. Coleção Artigas, tomo 8, p. 202.

26 CARTA DE Pedro Fagundes de Oliveira ao Governo Econômico. Guarda de Bagé, 02 de noviembre de 1813. ANRJ. Coleção Artigas, tomo 8, p. 210.

27 Idem. 
28 CARTA DE Pedro Fagundes de Oliveira a Xavier Curado. Guarda de Bagé, 10 de noviembre de 1813. ANRJ. Coleção Artigas, tomo 8, p. 429-430.

29 OFíCIO DE Nicolás Rodriguez Peña a Nicolás Herrera. Montevidéu, $1^{\circ}$ de agosto de 1814. ANRJ. Coleção Artigas, tomo 15, p. $183-184$.

30 NOTA CIRCULAR dirigida por Manuel Estanislao Soler ao Cabildo de Montevidéu. Montevidéu, 11 de noviembre de 1814. ANRJ. Coleção Artigas, tomo 16, p. 139.

31 OFICIO DE José Artigas al Capitán General de Porto Alegre, Marqués de Alegrete. Quartel do Paraná, 31 de marzo de 1815. ANRJ. Coleção Artigas, tomo 30, p. 218.

\section{REFERÊNCIAS BIBLIOGRÁFICAS:}

ALADRÉN, Gabriel. Sem respeitar fé nem tratados: escravidão e guerra na formação histórica da fronteira sul do Brasil (Rio Grande de São Pedro, c. 1777 - 1835). Niterói: Universidade Federal Fluminense, 2012. [Tese de Doutorado].

ANDREWS, George. Los afroargentinos de Buenos Aires. Buenos Aires: Ediciones de la Flor, 1989.

ARMITAGE, David. "Declaraciones de independencia, 1776 - 2011: del derecho natural al derecho internacional". ÁVILA, Alfredo, DYM, Jordana; PANI, Erika (orgs). Las declaraciones de Independencia: los textos fundamentales de las independencias de americanas. México, D.F: Colegio de Mexico, 2013. p. 19-40.

BERNAND, Carmen. Los olvidados de la revolución: el Río de la Plata y sus negros. Nuevo Mundo Mundos Nuevos [Online], Colóquios, 2010.

; QUIJADA, Monica; SCHNEIDER, Arnd (org.). Homogeneidad y nación con un estudio de caso: Argentina, siglos XIX y XX. Madri: Consejo Superior de Investigaciones Científicas, 2000.

BLACKBURN, Robin. A queda do escravismo colonial (1776-1848). Rio de Janeiro: Record, 2002.

BUSHNELL, David. A independência da América do Sul espanhola. In: BETHELL, Leslie (org.). História da América Latina. Da independência a 1870. São Paulo/Brasília: Edusp/Funag, 2001. p. 119-186.

CHUST, Manuel. Reflexões sobre as independências ibero-americanas. Revista de História, São Paulo, n. 159, p. 243-262, 2008.

CHAVEZ, María Eugenia. Revoluciones esclavas en el contexto de la independencia: el caso del Ecuador. Anais do XXVIII Congresso Internacional da Associação de Estudos Latino-americanos. Rio de Janeiro, p. 1-21, 2009.

FERREIRA, Gabriela. Conflitos no Rio da Prata. In: GRINBERG, Keila; SALLES, Ricardo. O Brasil imperial (1808 - 1831). Rio de Janeiro: Civilização Brasileira, 2014.

FREYRE, Gilberto. Casa grande e senzala. 50ª edição. Global Editora. 2005. (1ª edição 1934).

GOLDBERG, Marta B. Afrosoldados de Buenos Aires en armas. In: MALLO, Silvia; TELESCA, Ignacio (org.). Negros de la patria. Los afrodescendientes en las luchas por la independencia del Río de la Plata. Buenos Aires: Editorial SB, 2010. 
O RIO DA PRATA, A INDEPENDÊNCIA E A ABOLIÇÃO: PERSPECTIVAS DE LIBERDADE DOS ESCRAVOS NO ALÉM-FRONTEIRA

GOLDMAN, Noemí. Crisis imperial, revolución y guerra (1806-1820). In: (org.). Nueva Historia Argentina. Revolución, república, confederación (1806 - 1852). 2. ed. Buenos Aires: Sudamericana, 2005.

; TERVANASIO, Marcela. La vida política. Argentina. Crisis colonial e independência. Madri: Fundação Mapfre/Taurus, 2010. Colección América Latina en la Historia Contemporanea.

GRINBERG, Keila. Escravidão, alforria e direitos no Brasil oitocentista: reflexões sobre a lei de 1831 e o "princípio da liberdade" na fronteira sul do Império Brasileiro. In: CARVALHO, José Murilo de (org.). Nação e cidadania no Império: novos horizontes. Rio de Janeiro: Civilização Brasileira, 2007.

GUERRA, François-Xavier. La desintegración de la monarquía hispánica: revolución de independencia. In: ; ANNINO, A; LEIVA, L. CASTRO (org). De los imperios a las naciones: Iberoamerica. Paris: Ibercaja, 1994.

JOHNSON Lyman. La manumisión de esclavos en Buenos Aires durante el Virreinato. Desarollo Económico, v. 16, n. 63, p. 333-348, 1976.

; SOCOLOW, Susan M; SEIBERT, Sibila. Población y espacio en el Buenos Aires del siglo XVIII. Desarollo Económico, v. 20, n. 79, p. 329-349, 1980.

MÄDER, Maria Elisa Noronha; PAMPLONA, Marco A. (org.). Revoluções de independências e nacionalismos nas Américas: região do Prata e Chile. São Paulo: Paz e Terra, 2007.

MALLO, Silvia; TELESCA. Ignacio. Negros de la Patria. Los afrodescendientes en las luchas por la independencia en el antiguo Virreinato del Río de la Plata. Buenos Aires: SB, 2010.

MARTÍNEZ, Miguel Molina. Pactismo e independencia en Iberoamerica, 1808 - 1811. Revista de estudios colombinos, Valladolid, n. 4, p. 61-74, 2008.

NEVES, Lucia Maria Bastos P. Independência. Contextos e conceitos. História Unisinos, Porto Alegre, v. 14, n. 1, p. 5-15, 2010.

PIMENTA, João Paulo G. Estado e nação no fim dos impérios ibéricos do Prata (1808-1828). São Paulo: Hucitec, 2002.

SCHWARTZ, Stuart B. "A historiografia dos primeiros tempos do Brasil Moderno: tendências e desafios das duas últimas décadas". História: questões e debates. Curitiba, n. 50, p. 175-216, 2009.

SECRETO, Maria Verónica. Novas perspectivas na história da escravidão. Tempo, Niterói, v. 22, n. 41, p. 442450, set.-dez. 2016.

SOCOLOW, Susan M. Recent Historiography of the Río de la Plata: Colonial and Early National Periods. The Hispanic American Historical Review.,Durham, NC, v. 64, n. 1, p. 105-120, 1984.

STUDER, Elena F. S. de. La trata de negros en el Rio de la Plata durante el siglo XVIII. Buenos Aires: Libros de Hispanoamerica. 1984.

TANNEMBAUM, Frank. Slave and Citizen. The negro in the Americas. New York: Alfred A. Knopf, 1946.

WASSERMAN, Claudia (org). História da América Latina: cinco séculos (temas e problemas). Porto Alegre: Editora da UFRGS, 1996. 
